The International Journal of Engineering and Science (IJES)

|| Volume || 6 || Issue || 5 || Pages || PP 29-33 || 2017 ||

ISSN (e): $2319-1813 \operatorname{ISSN}$ (p): $2319-1805$

\title{
Analysis of Service Facility Economic Capability on Districts in South Konawe Regency
}

\author{
Tibertius Nempung ${ }^{1,}$ Aris Purwandi ${ }^{2}$ \\ ${ }^{1,2}$ Department of Economic, Faculty of Economics and Business Halu Oleo University, South East Sulawesi, \\ Indonesia
}

\begin{abstract}
-
This research is to find out the ability of service function from aspect and know ability of economic service of a market in a region. The population is used by hierarchy of market diversity ability, scalogram technique analysis, gravity analysis of trader orientation flow in South Konawe, data taken by 28 wholesalers and 24 collecting traders in all districts. Census sampling, the result of the scalogram economic service function in subdistrict is still weak and weighted centrality index, considered the lack of service facilities, only Ranomeeto district that have a strong enough ability and are in the first hierarchy with the index value of 345.9 is high enough with point 15 facilities. Non-physical aspects show districts, Konda,Moramo, Wolasi has a range Konda and Ranomeeto has the ability to interact three districts with LDTR values of 1.
\end{abstract}

Keywords: Capability, Service facility economic, South Konawe Regency

Date of Submission: 04 May 2017 Date of Accepted: 24 May 2017

\section{INTRODUCTION}

Accordance with Law No. 23 of 2014 on regional economics and local government, the granting of autonomy as wide as possible to the region is directed to accelerate the realization of community welfare through improving services, empowerment and community participation. In addition, through broad autonomy, in the strategic environment of regional globalization in hopes to increase competitiveness and efficiency in increasing the potential of the region and justice in the implementation of development. Development of areas applied in Indonesia according to law no 26 of 2007 on spatial arrangement provides an opportunity to build a more open area with a strategy for social economic services in the form of distribution of service centers. Therefore, the distribution and service of facilities at the service centers is a function of the spatial structure, then the distribution of these functions is crucial not only to promote economic growth and welfare of society but also for the socio-economic equity of a region. The gap in the economic welfare and social often measured through the number and diversity of productive and social functions in an area of each sub-district and in the avoidance of inequality access to economic and social facilities for the community. South Konawe Regency is part of the development area of Southeast Sulawesi province, which functions as a city of agricultural and agricultural commodities accumulation fisheries need a new growth center in order to anticipate the potentials and problems of regional development in South Konawe various potential that exists to improve the development process in South Konawe is wide enough to cover the land area of mainland districts of South Konawe, 451,420 hectares or 11.83 percent of the land area of southeast Sulawesi. While the area of waters (sea) $\pm 9,368 \mathrm{~km} 2$. The condition of the area is wide enough then the South Konawe has the opportunity to expand the region in line with the development of the current southern konawe population as many as 97,267 people (2014).

In general, the potential of development is sufficient, because it is supported by the potential service area function, such as in Ranomaeto district to the airport and other supporting facilities, as potential horticultural areas to be developed, Wolasi district with protected forest areas and surrounding areas fertile land and suitable for holticultura, West Ranomaeeto district with plantation area, Kolono district and Laonti with the potential of sea port which has wider access in connection with the surrounding district, Moramo district and North Moramo district with potential of marble mine and harbor the potential can be made into a central area or growth region by Perroux in Adisasmita (2014) which states that development or growth does not occur in all regions, but limited to certain places only with variable varying intensity. The successes that occur in the center of the spreading will be spread to the surrounding areas of activities with various activities with various social economic activities, in the opinion of Hirschman that is the impact of the tricking down effect or the concept of Mirdal namely the impact of spread effect and an activity against activity other, so that the region is more advanced. Rondinelli (1993), Stating, that a region is not only a functional settler system, it is a network of social, economic and physical interactions. In the form of linkages between settlements. In the spatial interaction of distance factors also influence, interaction with one another that the closer the distance of the intensified 
activity or intensity of the interaction. Therefore, the ability of the service of economic facilities that support the movement of economic activity in a region. One of the economic facilities that strongly supports economic growth and market availability. Markets are places or locations where goods and services are transacted between the seller and the buyer. According to Muilidian (1993), in the micro scale the market is also the terminal of various kinds of transportation. In the micro scale the market is a transportation center where the system of goods and services is distributed. As the center of economic activity. The market is expanding its economic activities. In the field of production, the market provides capital needs, Tools and energy, communications, the market provides primary and secondary needs. In the macro-scale of the market is a transportation center where the system of goods and services is distributed as a center of non-economic activity, the market serves as a place of recreation, information exchange, social gatherings and government.

In general, the existing markets in districts in South Konawe still in the form of traditional markets so that the government needs to pay attention. In addition to the presence of messages and other social facilities, the flow of goods and services of each district increased, so that economic progress can be increased in the region. The number of markets in the district of South Konawe, shows that.

Table 1. Number of Markets by Type in District of South Konawe

\begin{tabular}{|c|l|c|c|}
\hline \multirow{2}{*}{ No. District } & \multicolumn{2}{|c|}{ Markets } \\
\cline { 3 - 4 } & & Permanent & Non Permanent \\
\hline 1 & Konda & 2 & - \\
\hline 2 & Wolasi & 1 & - \\
\hline 3 & Ranomeeto & 2 & - \\
\hline 4 & Moramo & 6 & - \\
\hline 5 & Moramo utara & 2 & 9 \\
\hline 6 & Ranomeeto barat & - & - \\
\hline 7 & Kolono & 1 & 10 \\
\hline 8 & Laonti & 2 & \\
\hline Total & & 16 & \\
\hline
\end{tabular}

Source : BPS Prov. Sultra (South Konawe ,2015)

\section{THEORETICAL REVIEWS}

\subsection{Nodal area}

The central function of a city center is as a service center for the backward (complementary area), which supplies central goods and services such as retail services, trade, banking, professional, facilities, education, entertainment, and municipal services. These services can be arranged in ascending and descending order depending on demand threshold i.e. the minimum level of demand required to support economic services and the demand range of outer and market boundaries for each service that can lead to a hierarchy of a region such as the city and back areas that are mutually related.

\subsection{Growth Center}

The central growth theory by Boudeville. According to Boudeville (french economist), the center of growth is a collection of geographical phenomena of all existing activities. A city or city area that has an industry or a variety of activities can be said to be a growth center with the existence of a driving industry that can promote economic activity or other small industries. Furthermore, the driving industry has had a major, direct or indirect effect on other economic activities in the region. So that area is growing faster even more so if the government provides facilities as long as needed in the region, then the impetus to go forward stronger.

\subsection{Service Facilities}

According to Dusseldrop (1971), one of the functions of the subdistrict city as a center is to have a service function by providing basic facilities for the rear community and the majority of important service facilities are concentrated in it. The effectiveness of the function of socio-economic facilities is influenced by the number and quality of service facilities and geographical dispersal of these service facilities to function optimally if there is a minimum number of people in need to utilize these facilities. According to Dusseldrop in Setiawan (2016), the problem of good service facility that concerns Location and quality and quantity, closely related to the level of community welfare. Development can not run smoothly if service facilities are not available properly. So the service facility can be considered as a potential factor in determining the future of the development of an area both urban and rural so that efforts to increase economic development should continue to be improved especially in a region, especially newly developed areas.

According to Issar In Adisasmita (1994), essential services and facilities should be allocated to places that have a considerable population concentration or a region or a market area large enough to support economically economic activity, as such a location would Impacts on location economies, scale economies and urbanization economies. So if economic development is to achieve wider social and geographical equity, investments must be 
undertaken in a decentralized concentration pattern. Therefore they should be located in certain places that have strategic settlements that serve the communities living around them, with the facilities provided.

\subsection{Inter-Area Interactions}

According to Sujatmiko (2014), states that interconnection is a reciprocal relationship of mutual influence between two or more regions, which can cause various activities, symptoms, which affect each other both social, economic and political factors. Interaction is not only limited to the mobility of society, but also concerns goods and services with transportation and information that creates the interrelations of activities between them mutually. Binarto's view (1993) states that the relationship between two or more regions and the result of that contact Medium or has occurred in general can be interpreted as an interaction, which is a social potential, economic process and cultural process or political process as sooner or later.This as the dynamics of life bermasyarakat.Suatu region not only a residential system in a functional, but a network Social, economic and physical interactions. The interaction process is shaped by the linkages between settlements in the region through these linkages villagers receive various inputs needed to improve agricultural productivity and marketing of goods produced. In the spatial interactions of distance factors also influence, that the closer the distance the more intensive the perception and interaction of society (Rondinelli, 1985).

\subsection{Market System In Regional Development}

According to Smith (1976), the market can be viewed from two points of view. First is the view of Adam Smith and his followers who see market equilibrium as the forces of demand and supply that will form balance in the long run, this system will regulate regulating the allocation of scarce goods and resources through the price mechanism can also on many commodities. Secondly, the market is a natural human activity in the activity of life and establishes the specific conditions for growth due to reciprocal relationships.

One of the most obvious forms of intensity of market activity is the timing of such market activity in relation to the number and level of life of the population and the varying volume of goods Which is needed in the activity tersebut.Pasar in differentiate into two types namely:

A. The fixed market, a relatively large market in which people can buy all their necessities and sell their products daily. This market has an area of influence based on centralistic principles, as well as hinterland transportation and good accessibility, for example the city market district.

B. Periodic markets or periodic markets, ie markets with only 1-3 meetings per week, relatively small, commercially traded commodities are also limited and the markets are community meetings from various villages and hinteland with a particular pattern.

As the center of economic activity, the market facilitates economic activities. Good production, providing a variety of needs including services, tools and personnel. Consumption needs or, the market serves as a place of recreation, exchange of information, social gatherings and so on. The main factors that support the ongoing market activity are the existence of road networks and transportation facilities, so the mobility of people, goods and services depends on the presence or absence of this transportation facility. The development of wilyah economy with the function of transportation and access road, so that the subdistrict access based on the distance and direction of orient oriented traders in marketing their merchandise. The above phenomena, the existence of markets as economic service facilities that exist in sub-districts in southern konawe need to know the ability both physically and non physically in improving economic activity that can promote economic growth, the researchers are interested to conduct a study entitled.

\section{RESEARCH METHODS}

Referring to the background of the problems that have been put forward, then the issues to be examined are: The purpose of the study to know the functional capability of economic service physical aspects of each districts in South Konawe Regency and the economic service capacity of each districts in South Konawe Regency.Then a contribution in science to improve knowledge in regional development as well as application of various analyzes such as gravity analysis, scalogram and merchant orientation matrix in South Konawe Regency.

The scope of this study the function of economic services, covering 8 districts of Konda, Ranomeeto, West Ranomeeto, Moramo, North Moramo, Wolasi, Kolono and Laonti. In the ability of function of economic service from physical aspect include facilities that exist in market and individual service around market area while economic service ability from non-physical aspect that is economic interaction from aspect of distance. Population number and direction of trader orientation flow contained in districts. Simple random sampling intentionally analyzing data with scalogram, gravity analysis then analysis of merchant orientation current matrix in South Konawe Regency. 


\section{RESULTS AND DISCUSSIONS}

\subsection{The Capability of Economic Service Facilities from The Physical Aspect of Market At Districts In South Konawe Regency}

The results of research conducted using a scalogram analysis showed that the ability of economic service facilities from the physical aspect of the market is the availability of diversity of facilities contained in the market at districts in South Konawe Regency is still weak.Only Ranomeeto district that has the ability of facilities is relatively adequate based on the number of facilities and the value of the centralized index is weighted so that the Ranomeeto district has greater penetration potential for future development of space. So that the districts have the potential for economic development in the region of South Konawe, with various economic service facilities can trigger the growth of goods and services flow "from" and "to" various regions or orientation activities at high intensity.

\subsection{The Capability of Economic Service from Non-Physical Aspect of Market At Districts In South Konawe Regency}

The ability of economic service of non market physical aspect by using gravity analysis and merchant orientation current matrix which is measured from the level of interaction based on distance, the number of population and the direction of trader orientation flow. The research results obtained by the average of districts in South Konawe Regency are only able reach three to four districts which generally includes direct border districts. Konda district with population 19,861 people can reach four subdistricts. This phenomenon is in line with Rondinelli (1985) opinion that a region is not just a functional residential system, but a network of social, economic and physical interactions. The process of interaction is in the form of linkages between settlements, or through the interconnection between villagers who receive the various inputs needed to improve agricultural productivity and marketing of goods produced as well as spatial interactions of distance factors influence the economic and social activity closer the more intensive the perception and interaction of people in the region. The result of the analysis of trader orientation current matrix, the ability of economic service based on the level of interaction of traders "from" and "to" various regions between districts in South Konawe Regency shows that the interaction that occurs in these districts is still weak. The condition is in because of the lack of competition among traders between districts. The extent of territory and population is still limited. Showing only Ranomeeto districts and with LDTR value 0.42 has relatively strong trader orientation competition among other districts and sub-districts interact with three other sub-districts. To stimulate economic growth, interaction can create inter-regional linkages as well as development territory of all districts in South Konawe Regency need to intervene local government.

\subsection{Conclusions}

\section{CONCLUSIONS AND SUGGESTIONS}

The results of research can be drawn some conclusions as follows:

1. The ability of the function of social economic service in South Konawe Regency in review of the physical aspects of district is still weak, this is according to the result of scalogram analysis from Weighted Centralized Index (WCI) which shows the lack of availability of social economic service facility only Ranomeeto district which has strong enough ability And is in the first hierarchy and the highest weighted index value of centralization is 345.9 in the measure of the availability of diversity of economic service facilities with 15 points of facilities in the district.

2. The ability of economic service from the non-physical aspects of South Konawe Regency shows Konda district, Moramo district and Wolasi district have wider service coverage capability because it can reach four districts from eight districts, especially east of South Konawe Regency. It is dominated by the large number of residents, the closeness of the distance between the center of the capital district so that the high attractiveness of the region. While the result of flow analysis of trader orientation among districts. It shows that Ranomeeto district has the ability to interact with three districts with LDTR value of 1 .

\subsection{Suggestions}

1. The policy direction of the district government of South Konawe Regency requires the improvement or development of social economic facilities, especially the market, in order to rehabilitate the social economic facilities to strengthen the capacity of services to encourage social economic growth to increase.

2. The South Konawe Regency government in each district is needed or creates interlingkage between service centers efficiently. Both economic and social for the whole society. 


\section{REFERENCES}

[1]. $\quad$ Adisasmita, Rahardjo, 2005. Dasar-Dasar Ekonomi Wilayah penerbit Graha Ilmu Yogyakarta

[2]. Adisasmita, Rahardjo,2008 Pengembangan Wilayah Konsep Dan Teori. Penerbit Graha Ilmu Yogyakarta.

[3]. Adisasmita, Rahardjo, 2014 Pertumbuhan Wilayah Dan Wilayah Pertumbuhan Graha Ilmu Yogyakarta

[4]. Anggraeni Yuyun, 2015 Analisis Perkembangan Kawasan Strategis Kota Kendari, Fakultas Ekonomi Dan Bisnis UHO.

[5]. Arsyad, Lincoln. 1999. Pengantar Perencanaan Pembangunan Ekonomi Daerah Yogyakarta: BPFE.

[6]. Badan pusat statistic (BPS), Kabupaten Konawe Selatan Dalam Angka 2015.Bintarto, R. 1993. Analisis Geografis LP3ES

[7]. Matoka, U. 1994. Studi Jangkauan Pusat Pelayanan Pertumbuhan Di Sulawesi Tenggara (Tesis, Program Magister Perencanaan Pengembangan Wilayah Pasca Sarjana Universitas Hasanudin, tidak di publikasikan).

[8]. Misriatun, 2008Analisis Pusat-Pusat Pelayanan Di Kabupaten Kolaka Bagian Timur(Tesis, Program Magister Perencanaan Pengembangan Wilayah Pasca Sarjana Universitas Haluoleo, tidak di publikasikan ).

[9]. Mahi, la. 2009 Analisis Hirarki Pusat-Pusat Pelayanan Pada Perwilayahan Pembangunan Di Kabupaten Muna. Tesis, Program Magister Pasca Sarjana Universitas Haluoleo; Kendari.

[10]. Maulidian, N. 1993 Analisis Perkembangan Struktur Tata Ruang Wilayah Transmigarasi. Studi Kasus Di Proyek Karang Agung Tengah. Kabupaten DT II Banyu Asin. Tesis Fakultas Pascasarjana IPB Bogor.

[11]. Peraturan Menteri Dalam Negeri Republic Indonesia Nomor 20 Tahun 2012 Tentang Pengelolaan Dan Pemberdayaan Pasar Tradisional.

[12]. Rondinelli. D.A, 1985 Applied Methods Of Regions Analysis: The Spatial Dimension Of Development Policy. Westwive Pres. London.

[13]. Smith, C.A. 1976. Regional Analysis Volume I Economic System Academic Press New York

[14]. Syamsul, La Ode 2013 Analisis Fungsi Kecamatan Di Bagian Barat Kabupaten Muna.Tesis Program Magister. Perencanaan Pengembangan Wilayah Pasca Sarjana Universitas Haluoleo tidak di publikasikan.

[15]. Undang-Undang No 23 Tahun 2014. Tentang Pemerintah Daerah.

[16]. Undang-Undang No 20 Tahun 2007. Tentang Penataan Ruang

[17]. Van Dusseldrop D.B.W.M 1971. Planning Of Cervice Centres In Rural Areas Of Developing Countries, International Intitute For Land Reclamation And Improvement. Nederland

[18]. Warpani Suwardjoko, 1981. Analisis Kota Dan Daerah, Penerbit ITB, Bandung 